\title{
Shakespeare's Joan and the Great Whore of Babylon
}

\section{PATRICK RYAN}

Inconfortables avec le portrait injurieux que fait Shakespeare de Jeanne d'Arc, les critiques tendent à considérer 1 Henry 6 comme un exemple de défaut d'expression relevant de la période d'apprentissage de l'auteur dramatique. Néanmoins, le public élisabéthain a reçu cette pièce de théâtre d'histoire avec un extraordinaire enthousiasme, conduisant les critiques féministes à étudier la Jeanne d'Arc de Shakespeare en tant que portrait remarquablement mobilisateur de la femme forte aux prises avec le patriarcat des débuts de l'époque moderne. Cet article examine l'utilisation dans 1 Henry 6 de l'idéologie apocalyptique protestante, en particulier de ses composantes misogynes. Plus précisément, Shakespeare présente Jeanne d'Arc, la sainte guerrière française, comme un avatar de la Grande Prostituée de Babylone, figure allégorique du Livre des Révélations, et, pour les protestants élisabéthains, figure de l'Église catholique romaine.

How would it haue ioyed brave Talbot (the terror of the French) to thinke that after he had lyne two hundred yeares in his Tombe, hee should triumphe againe on the Stage, and haue his bones newe embalmed with the teares of ten thousand spectators at least, (at seuerall times) who in the Tragedian that represents his person, imagine they behold him fresh bleeding.

$\mathrm{W}$

ith these words, Thomas Nashe describes audience response to premier performances of Shakespeare's 1 Henry 6, a chronicle play climaxing with the death of England's Lord Talbot during battle against French forces in the Hundred Years' War. According to Nashe, "ten thousand spectators at least" attended 1 Henry 6 in London between March and June of 1592; however, Phyllis Rackin emphasizes that "Philip Henslowe's records of the receipts for" this "initial run suggest a figure closer to 20,000, more than all but one of the many other plays that Henslowe produced."1 Even though Shakespeare's contemporaries received the drama with such extraordinary enthusiasm, many

Renaissance and Reformation / Renaissance et Réforme, XXVIII, 4 (2004) /55 
modern critics have dismissed the work as a flawed expression of the young playwright's theatrical apprenticeship, particularly in his characterization of Joan of Arc. ${ }^{2}$ Indeed, Shakespeare portrays Joan as a whorish witch and conjuror, exaggerating even the English chroniclers' calumnies against her. ${ }^{3}$ Whereas traditional scholars, unsettled by Shakespeare's "slanderous" attacks against Joan and England's French enemies, have tended to ignore 1 Henry 6 , feminist critics, recognizing its powerful effect upon Elizabethan audiences, study the drama as theatrical exploitation of early modern misogyny, with Joan a figure of the strong woman who subverts patriarchal authority. ${ }^{4}$ In this article, I examine Shakespeare's use of Protestant apocalyptic ideology, especially its misogynistic elements, to attack England's Roman Catholic foes. I focus primarily upon Shakespeare's Joan of Arc: embellishing and contradicting historical sources, he paints her in the image of the Great Whore of Babylon, an allegorical character in St. John's Book of Revelation and, for Elizabethan Protestants, the archetypal witch who personifies the church of Rome.

In my critical approach to 1 Henry 6, I consider the historical moment of its production and argue that Shakespeare staged his chronicle play to advance a major ideological project of Queen Elizabeth's church and state: to steel her subjects for prolonged, uncertain struggle against Spain and its French allies in the Catholic League. Tudor chronicles of the reign of England's King Henry VI lent themselves to Shakespeare's purpose. As Geoffrey Bullough has shown, Henry's defeat in France "would be topical at the end of 1591," when Elizabeth's troops were battling for the Protestant cause against French Catholic enemies at Orleans, where Joan had triumphed, and at Rouen, where she had perished in the flames of an English pyre. ${ }^{5}$ Protestant apocalyptic also lent itself to Shakespeare's purpose. In his depiction of Joan as an avatar of the Great Whore, he exploited a staple of Reformation doctrine: that Rome was St. John's Babylon soon to be destroyed by the army of true Christians, God's elect waging holy war against the forces of Antichrist during "the last times." 6

\section{II}

With his Actes and Monuments of These Latter and Perillous Dayes, John Foxe warns Elizabeth's subjects to prepare for imminent apocalypse. Foxe declares unequivocally that "the last times" began during the reign of Henry VI with "grievous and sundry persecutions raysed by Antichrist."7 Accordingly, Shakespeare frames his first Henriad within the Tudor apocalyptic schema of history. Part One begins with the funeral of Henry V, the hero-king whose 
untimely death would nullify his victories in France and result in England's expulsion from her territories there. The opening lines of the play, a series of funeral laments, invoke images of Doomsday. First, the Duke of Bedford exhorts the day to darken and comets to appear:

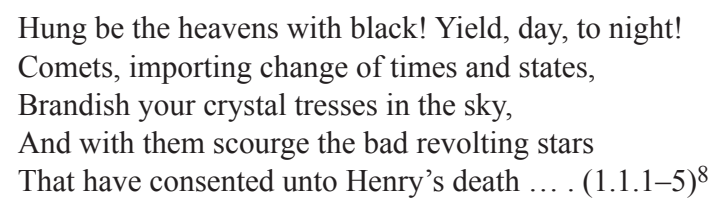

Bedford's lines recall verses from the Hebrew prophets and from the gospels, especially Jesus' prophecy that "the sunne [shall] be darkened ... and the starres shal fall from heaven," these cosmological portents signaling "the end of the worlde" after horrific "tribulation" (Matt. 24.29,3). ${ }^{9}$

The Duke of Gloucester takes up the lament with his description of Henry V drawn from commonplace apocalyptic iconography:

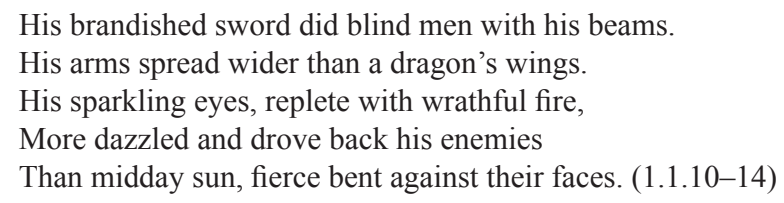

Gloucester attributes to Henry V characteristics of the Son of Man as depicted in St. John's apocalyptic visions: the Son of Man, whose "eyes were as a flame of fyre," whose "face shone as the sunne shinneth in his strength," whose "sharpe two edged sword" threatens the wrath of an angry God (Rev. $1.14-16$ \& 19.12-16).

Not only Reformation exegesis but also Renaissance art and poetry disseminated this biblical figure among Shakespeare's audiences. With a series of woodcuts illustrating the Book of Revelation, Luther's September Bible introduces a late medieval iconographic tradition into early Protestant bibles. The first cut in Luther's Bible depicts the Son of Man, his "eyes a flame of fire" and his face shining like the sun (fig. 1). ${ }^{10}$ Similarly, an English translation of Jan Van der Noot's Theatre for Voluptuous Worldlings, published in 1569 , includes a woodcut in which the Son of Man rides to battle in the sky, his "brandished sword" blinding "men with his beams". ${ }^{11}$ In Shakespeare's version of the image, Henry V's "arms spread wider than a dragon's wings," a detail recalling St. John's "great dragon, that olde serpent, called the deuil and Satan" (Rev. 12.9), the biblical model for Edmund Spenser's dragon overcome by Redcrosse Knight in Book One of The Faerie Queene. ${ }^{12}$ 
58/ Renaissance and Reformation / Renaissance et Réforme

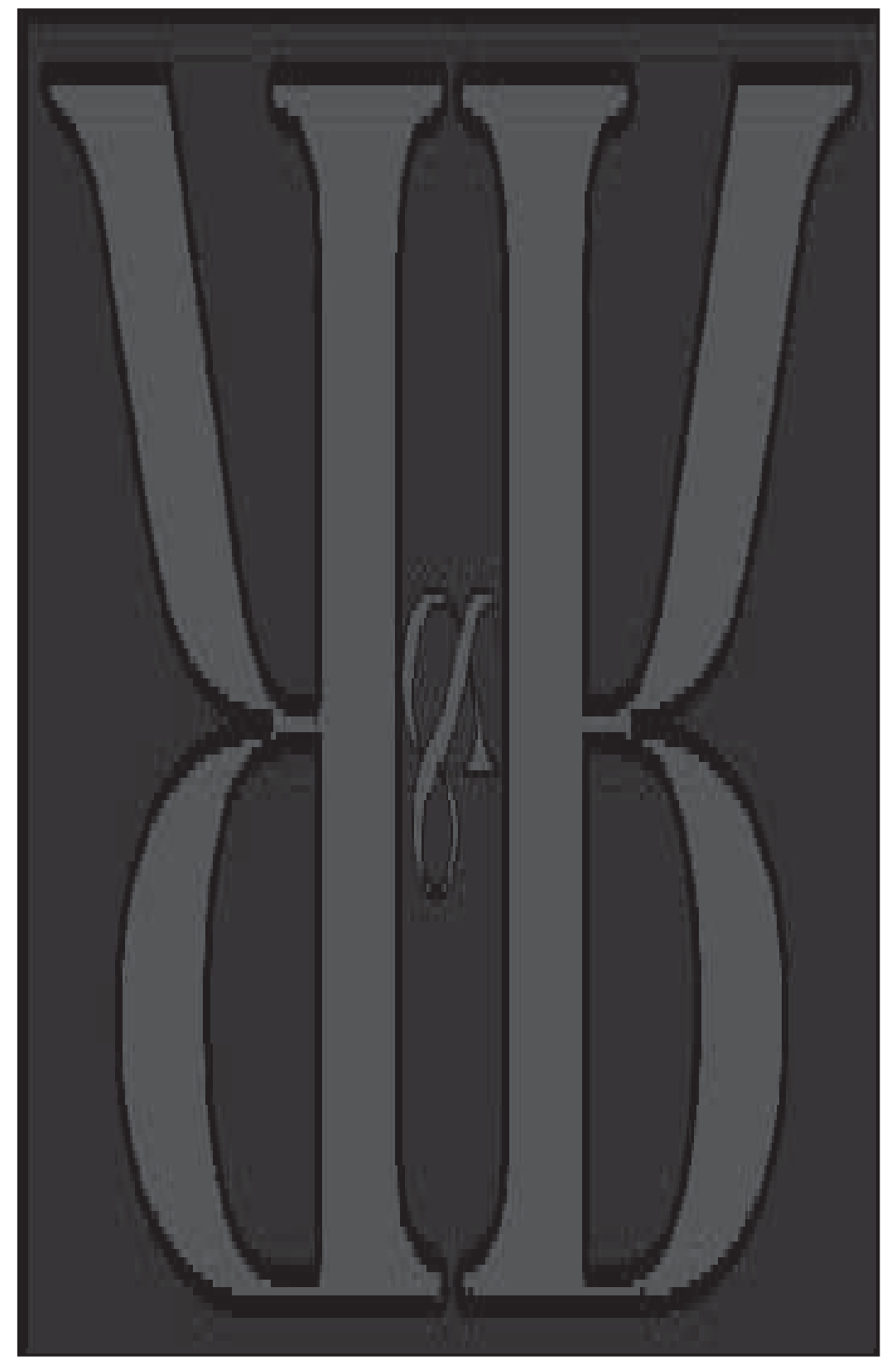

Fig. 1: One Like the Son of Man, Woodcut illustration of Revelation 1.14-16 in Martin Luther's Das Newe Testament Deutzsch (Vuittemberg, September 1522), also known as the "September Bible," reprinted courtesy of the Richard C. Kessler Collection, Pitts Theology Library, Candler School of Theology, Emory University. 
With the royal funeral ending, the Bishop of Winchester borrows terms from Revelation 19 to describe Henry $\mathrm{V}$ as an instrument of the King of Kings on a judgment day for England's French enemies:

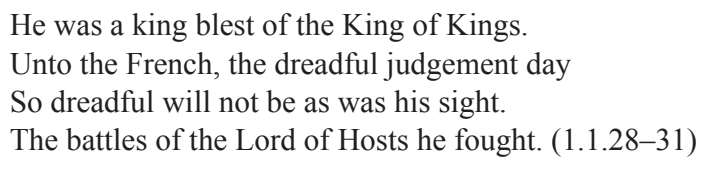

When Shakespeare's noble characters identify their fallen monarch with the apocalyptic Son of Man and King of Kings, they define England's cause against France as righteous, even holy. Later in the drama, when Shakespeare, borrowing symbolic actions from the Book of Revelation, associates Joan with the Whore of Babylon, he implies that England's French Catholic enemies battle as agents of Antichrist and Satan, a charge confirmed by authorized eschatology of Elizabeth's Protestant church: "Needs must" St. John's Whore "be Rome ... with all their abominations and devilishnesses, their idolatries" and "witchcrafts."13

When 1 Henry 6 first played in London, members of Shakespeare's audiences were quite prepared to recognize and respond to apocalyptic imagery. Along with a stream of doomsday tracts and popular prophecies, ${ }^{14}$ Foxe's Actes and Monuments heightened expectation among Elizabeth's subjects that the End was near. In his edition of 1570, Foxe proclaimed with certainty that 1586 would see the "full seventy years of the Babylonish captivity" draw "well nigh to an end," but "What the Lord [might] do with this wicked world," Foxe would not say. Popularly known as the Book of Martyrs, Foxe's apocalyptic church history, including his prophecy that the world would end in 1586, was read widely. ${ }^{15}$ The world did not end in 1586 . However, early in the following year, Elizabeth signed the warrant for the execution of Mary, the Catholic Queen of Scotland. After Mary's beheading in 1587, King Philip of Spain vowed to retaliate, and England began to prepare in earnest for Spanish invasion. Apocalyptic expectation was reconfirmed by a widely regarded prophecy that 1588 would see change among "empires and kingdoms," if the world were not destroyed; and so, when the Spanish Armada set sail for England in May of 1588, many feared Armageddon. ${ }^{16}$ After defeat of the Armada, apocalyptic anxieties heightened further as Elizabeth's fortunes grew even more precarious. In 1589 Philip of Spain was preparing for a second attempt to invade England when Elizabeth sent nearly 4,000 infantry to France in aid of the embattled Protestant King Henry of Navarre. In 1590, Spanish troops landed in Brittany and secured a military outpost, forcing Elizabeth in 1591 to send 3,000 soldiers to fight there. At the same 
time, Elizabeth's favourite, the Earl of Essex, was leading English troops to support King Henry in Normandy. ${ }^{17}$

When Shakespeare staged 1 Henry 6, England's position had grown desperate, and Protestant apocalyptic remained central in ideological designs to prepare English people for battle against their Catholic foes. Most notably, in 1590 Edmund Spenser published the first three books of The Faerie Queene. Book One, The Legende of the Knight of the Red Crosse, or of Holinesse, an historical allegory based in part upon St. John's Book of Revelation, prophesies eventual victory for Protestant England over the "anti-Christian" forces of international Catholicism. In this apocalyptic poem, Spenser's St. George, or the Knight of the Red Crosse, is seduced by Duessa, a personification of the Roman church modeled on the Whore of Babylon. Describing his Duessa as "A goodly Lady clad in scarlot red, / Purfled with gold and pearle of rich assay" ( $F Q$ 1.2.13), Spenser clothes her in garments of St. John's Great Whore: "the woman ... araied in purple \& skarlat, \& gilded with golde, \& precious stones, and pearles" (Rev. 17.4; fig. 2).

St. John prophesies that, in the last days, true Christians shall strip the Great Whore to make her "desolate and naked" (17.16). During a climactic passage of Spenser's Legende of Holinesse, Una, a figure of the true Protestant church, orders "that witch" Duessa to be stripped of her raiment; and so - naked, her ugliness exposed - the whore is divested of her seductive power over England's St. George ( $F Q$ 1.8.45-50). In a climactic scene of 1 Henry 6, Joan, her witch's charms broken, is stripped figuratively, her "fornications" exposed and her beauty revealed as meretricious. Thus, Shakespeare, embellishing and contradicting the historical record, portrays his Joan as an incarnation of the Great Whore and dramatizes a literary motif deriving from the Book of Revelation. ${ }^{18}$

III

The chronicler Edward Hall characterizes Joan's martial successes and her ultimate defeat in terms of the de casibus tradition, but emphasizes, instead of Fortune, "the deviles meanes" that gave her power "and inconclusion [sic] rewarded her with a shameful fal." 19 But Shakespeare, despite the Tudor chroniclers' expressed condemnations, gives no conclusive dramatic evidence through most of 1 Henry 6 that Joan receives power from Satan, not, as she claims, from God. ${ }^{20}$ Indeed, consonant with Protestant warnings to watch for "signs" of the End Times, the drama provides only indirect evidence that Catholic Joan la Pucelle rises through use of demonic powers. Before she is presented to Charles, the French Dauphin, he with his entourage contrives 
Patrick Ryan / Shakespeare's Joan and the Great Whore of Babylon /61

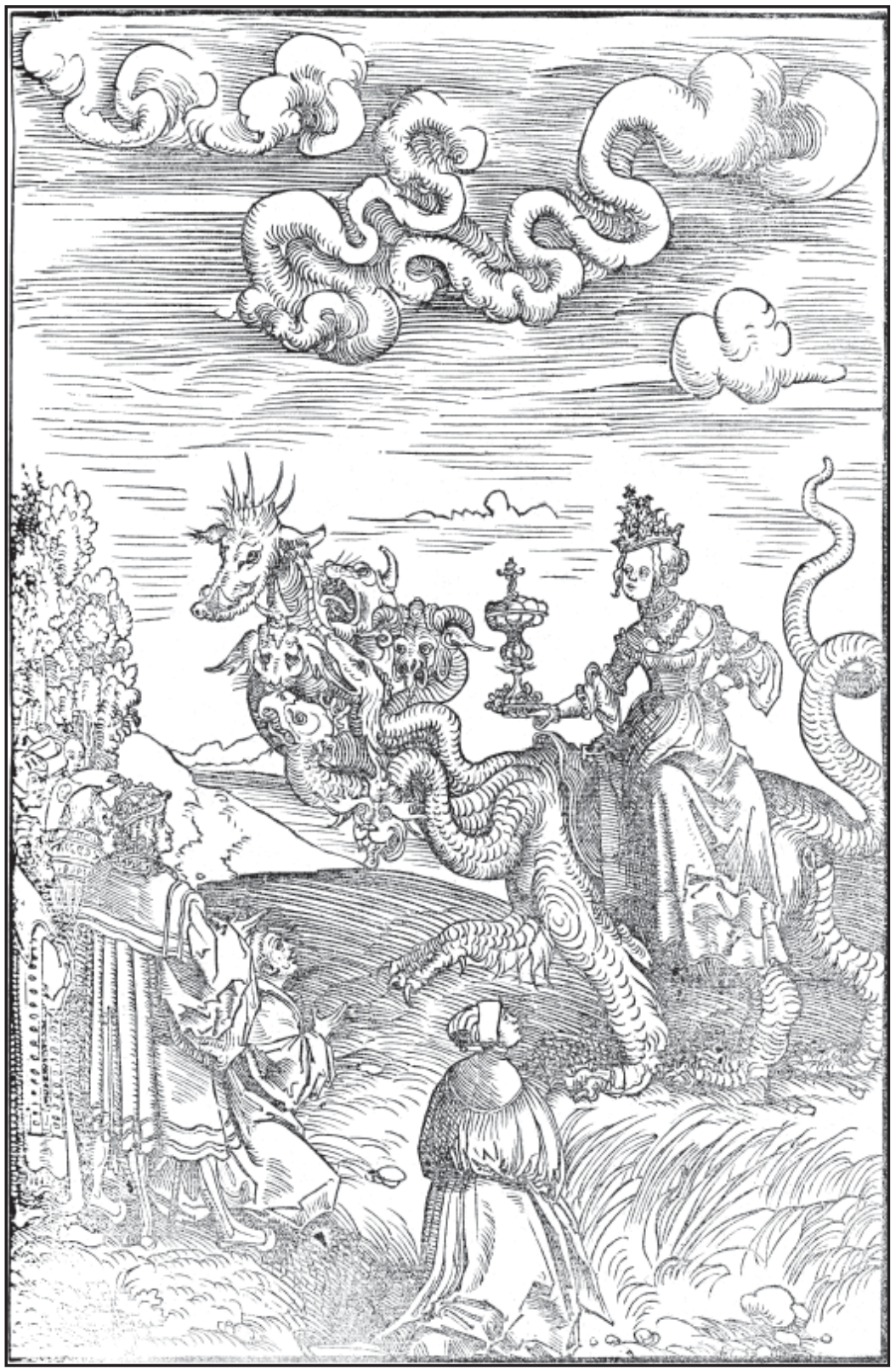

Fig. 2: The Whore of Babylon depicted with a triple crown like the pope's. Lucas Cranach's woodcut illustration of Revelation 17.4 in Martin Luther's Das Newe Testament Deutzsch (Vuittemberg, September 1522), also known as the "September Bible"; reprinted courtesy of the Richard C. Kessler Collection, Pitts Theology Library, Candler School of Theology, Emory University. 
to test her abilities as a "prophetess" divinely inspired. Charles hides among his nobles, one of whom, René, pretends to be the Dauphin; but Joan, not deceived for even a moment, asks, "René, is't thou that thinkest to beguile me?" before she commands the true Dauphin, "Come, come from behind./I know thee well, though never seen before." When the Dauphin responds, Joan reassures him: "Be not amazed. There's nothing hid from me" (1.3.4447). Hearing Joan's claim to be all-seeing, Protestants among Shakespeare's contemporary audiences were probably disposed to suspect that she practises sorcery; according to a demonological commonplace among Elizabethans, devils carry "newes from anie parte of the worlde" and "reveale" to witches "the secretes of anie persons." 11 In the same scene, Joan will boast, "Ask me what question thou canst possible,/And I will answer unpremeditated" (1.3.76-77).

After finding the Dauphin hiding among his nobles, Shakespeare's Joan refuses her place as a low-born woman. "In private will I talk with thee apart," she commands the Dauphin before dismissing members of his court: "Stand back you lords, and give us leave awhile" (1.3.48-49). Here, Shakespeare emphasizes that Joan, an "unnatural" prodigy, crosses gender boundaries to subvert patriarchal hierarchy; ${ }^{22}$ then, in her private monologue to the Dauphin, she displays "unwomanly" rhetorical power. She declares that her "wit" is "untrained in any kind of art" even as she sways him with the force of her rhetoric. To end her appeal, she insists, “ ... I exceed my sex./Resolve in this: thou shalt be fortunate/If thou receive me for thy warlike mate." The Dauphin admits to Joan, "Thou hast astonished me with thy high terms," before challenging her to duel: "In single combat thou shalt buckle with me,/And if thou vanquishest, thy words are true" $(1.3 .52,69-72$, 74-75). Joan wins the duel; the Dauphin yields, calling her "an Amazon" who "fight[s] with the sword of Deborah" (1.3.83-84). Such exaggeration of Joan's abilities suggests that they are conferred by devils, as Shakespeare will confirm later in the play when, in a scene of his invention, he shows her conjuring spirits from hell.

Shakespeare injects the supernatural further into his characterization of Joan with her account of the heavenly apparition that has made her alluring and has raised her from her lowly status. She reveals that, although she is "by birth a shepherd's daughter," God's mother has transformed her from foul to fair, from base shepherdess to woman warrior. She tells the Dauphin,

Heaven and our Lady gracious hath it pleased

To shine on my contemptible estate.

Lo, whilst I waited on my tender lambs

And to sun's parching heat displayed my cheeks, 


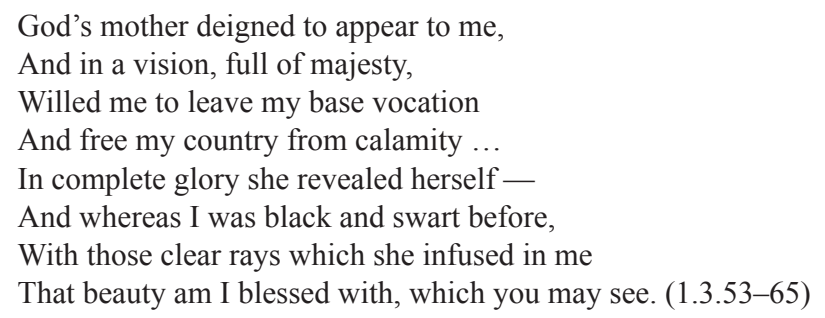

These lines combine contradictory elements of Hall's and Raphael Holinshed's descriptions of Joan. Hall remarks on her "foul face," but Holinshed describes her as manly and attractive: "Of favour was she counted likesome, of person stronglie made and manlie ... ." 23 When Shakespeare's Joan describes her transformation from a shepherdess "black and swart" under the "sun's parching heat," she inverts a well-known biblical image and associates herself with the "false" church of Rome, or, for militant Protestants, the Whore of Babylon. The Song of Solomon celebrates a lord's passion for a sun-darkened shepherdess who boasts, "I am blacke ... but comelie ... blacke: for the sunne hath looked upon me" (1.4-5). Adopting traditional medieval exegesis, Protestant divines read this poem as allegorical declaration of Christ the bridegroom's love for his bride, his true church. According to a gloss in the Geneva Bible, "In this Song, Salomon by moste swete and comfortable allegories and parables describeth the perfite love of Jesus Christ, the true Salomon and King of peace, and the faithful soule or his Church ... his spouse, holy, chaste, and without reprehension" (Argument). When Shakespeare's Joan boasts of her beauty and expresses contempt for her former appearance as "black and swart," a consequence of her "contemptible estate," she associates herself not with Solomon's shepherdess personifying the true church, but with the false church of Antichrist. "Consider not the Church by ye outward appearance," warns Protestant exegesis on these lines, a warning elaborated by Foxe, who condemns the "church or chapel of the devil," that is, the "church of Rome to be so visible and glorious in the eyes of all the world, so shining in outward beauty" that it is "supposed ... to be the only right catholic mother." 24

After defeating the Dauphin in their duel, Joan reassures him: "Christ's mother helps me, else I were too weak" (1.3.85). Disinclined to believe Joan, the Dauphin only admits his passion and willingness to submit himself to her:

Whoe'er helps thee, 'tis thou that must help me.

Impatiently I burn with thy desire ...

Excellent Pucelle if thy name be so,

Let me thy servant and not thy sovereign be ... (1.3.86-90). 
The Dauphin has been seduced, enthralled by a "termagent of antichrist's holy household," as John Bale, in the Preface to his Image of Bothe Churches, describes agents of Roman Catholicism who know "that over a gorgeous glittering whore every fleshly man is inordinately wanton." 25 In this early scene, with Joan's seduction of the French Dauphin, Shakespeare enlists "the iconography of corporeality" and the "semiotics of Revelation prophecy"- to use terms introduced by Claire McEachern in her analysis of misogynistic imagery in The Faerie Queene. ${ }^{26}$ Just as St. John's Whore seduces with her outward appearance, spirits from hell and then Duessa deceive Spenser's Redcrosse and seduce him from Una, the true Christian faith. McEachern shows that Elizabethan Protestants - imbued with images from Revelation, including the Whore as a figure of lust and idolatry - are inclined to read apocalyptic iconography encoded in the bodies of Spenser's female characters. Similarly, in 1 Henry 6 Joan invites the audience to examine and interpret her body when she claims that during a heavenly vision she has undergone transfiguration: "With those clear rays which [God's mother] infused on me/That beauty am I blest with, which you may see" (1.3.64-65). And when the Dauphin, after fencing with Joan, confesses to "burn with ... desire" and wishes to subject himself to her, members of Shakespeare's audience may recall how "fleshly man" becomes "inordinately wanton" over a "glittering whore" and how "carnal" desire leads to sexual idolatry.

Characterizing Joan as a "manly" seductress, Shakespeare works to excite a fear of witches that was growing as apocalyptic anxieties deepened during the great crises of Elizabeth's reign. ${ }^{27}$ Like John Bales's "glittering whore," witches were said to exercise their power to inflame irresistible sexual desire among their male victims. In his Daemonologie, King James reaffirms longstanding belief that witches afflict men not only with impotence but also with sexual obsession such as the Dauphin's sudden, consuming desire for Joan. Prominently in his book, James warns that witches have "proved their power in speciall: of weakening the nature of some men, to make them unable for women: and making it to abound in others, more then the ordinary course of nature would permit." 28 Tudor apocalypticism, identifying St. John's Whore of Babylon as the archetypal witch, adopts such elements of contemporary lore about witchcraft, giving it an implied scriptural authority. In 1 Henry 6, Shakespeare aims to evoke gynophobic responses implicit in contemporary witch-lore and apocalyptic ideology alike when he characterizes Joan as a whorish witch, an agent of the Great Whore. Ironically, during a climactic scene, Shakespeare allows the Dauphin to associate Joan with a notorious whore of Egypt. Vowing to "divide [his] crown" with Joan and to honour 
her as a holy saint, the Dauphin promises, "A statelier pyramid to [Joan] I'll rear/Than Rhodope's of Memphis ever was ... And all the priests and friars in my realm/Shall in procession sing her endless praise" (1.8.21-22 \& 19-20). According to legend, Rhodope was a prostitute who married the King of Memphis and built a great pyramid for her tomb. Seeing the Egyptian captivity of the Jews as a biblical type of the Babylonian captivity of the church of Christ, Bale calls Roman Catholic priests "those two-horned whoremongers, those conjurors of Egypt, and lecherous locusts leaping out of the smoke of the pit bottomless, which daily deceive the ignorant multitude with their sorceries and charms ...."29

After he is overcome in their duel, the Dauphin, intoxicated with desire, flatters Joan, comparing her to historical figures prominent in Protestant apocalyptic historiography. He likens Joan first to the prophet Mohammed: "Was Mohammed inspired with a dove?/Thou with an eagle art inspired then" (1.3.119-20). When 1 Henry 6 premieres, some Protestant controversialists have warned that there are two Antichrists: Mohammed and the Roman pontificate. ${ }^{30}$ In the Preface to his commentary on Revelation, Bale declares with rhetorical flourish that the "Romish pope" with his "execrable decrees" and "Mahomet" with his "wicked Alcoran," "being very devils with their filthy dregs of darkness," "are both of one wicked spirit." Tudor Protestant exegetes identify the Gog and Magog of Revelation 20 as the Roman church and the Islamic world, warning that during the last days these "two horns or beastly kingdoms of antichrist, or whole body of the devil," 31 would "gather them together to battle" against God's elect (Rev. 20.8). In Book One of his Faerie Queene, Spenser, too, emphasizes the diabolical kinship between Roman Catholics and Muslims. Most notably, when Redcrosse Knight, the "true Saint George," first encounters Duessa, she is accompanied by "her lover," the "faithlesse Sarazen" Sans foy, whom the Christian knight slays (FQ 1.2.12-13).

After comparing Joan's prophetic gifts to Mohammed's, the Dauphin compares Joan to "Helen, the mother of great Constantine" (1.3.121). In the fourth century, according to Church history, Helen converted her son the Roman Emperor Constantine to Christianity, thus guaranteeing orthodox Christians an end to Roman persecution. According to tradition, St. Helen led an expedition to Jerusalem, where she unearthed a remnant of the cross of Christ. A Protestant tract printed in 1559 flatters Elizabeth as "our English Helena" with her "desire to advaunce and promote the true doctrin of Christes crosse" against "the power of darkness" and "the membres of antichristes and Sathans garde." ${ }^{2}$ When Shakespeare's Dauphin compares Joan first to Mohammed, then to Helen, he betrays French Catholic confusion about true 
religion. The Dauphin finally calls Joan the "Bright star of Venus, fall'n down on the earth" and pledges that he will "reverently worship" her (1.3.123-24), thus conflating, in his sin of sexual idolatry, the Roman goddess of love with a falling star, a biblical sign of Doomsday.

Just before the Dauphin calls her a bright, fallen star, Joan proclaims, "Assigned am I to be the English scourge" (1.3.108). Indeed, her imminent victory at Orleans, a first step toward French triumph over England, seems an ironic fulfillment of Bedford's lament: "Comets, importing change of times and states,/Brandish your crystal tresses in the sky,/And with them scourge the bad revolting stars/That have consented unto Henry's death" (1.1.2-4). Calling herself a scourge of God, Joan characterizes her military career in terms of Tudor apocalypticism, which recognizes some warriors and tyrants as instruments of divine providence who inflict their cruelties upon cities and realms, thus visiting God's just judgment upon them. On the Elizabethan stage, Christopher Marlowe's Tamburlaine stands as the apotheosis of the apocalyptic "scourge of God and terror of the world." Before sacking Babylon and ordering all her inhabitants to be drowned, Tamburlaine threatens, "these terrors and these tyrannies ... I execute, enjoined me from above,/To scourge the pride of such as Heaven abhors ... In war, in blood, in death, in cruelty,/ And plague such peasants as resist in me/The power of heaven's eternal majesty" (2:4.1.140-44). In this climactic scene of The Bloody Conquests of Mighty Tamburlaine, Marlowe's "scourge of God" besieges Babylon, the scriptural type of Rome destroyed in St. John's Book of Revelation. ${ }^{33}$

Early in 1 Henry 6, Shakespeare's Joan, unlike Tamburlaine, does not destroy "such as heaven abhors," but relieves the besieged city of Orleans, saving it from God's Englishmen. As the scene opens, Lord Talbot, commander of the English force, attends to the Earl of Salisbury, a "mirror of all martial men" whose eye and "cheek's side" have been "struck off" by a gunner sniping from the walls of Orleans (1.6.52-53). With a stage direction, Shakespeare calls for thunder and lightning to herald the arrival of Joan. Talbot suggests that these are portents: "What tumult's in the heavens?" he asks before a messenger warns, "The Dauphin, with one Joan la Pucelle ... A holy prophetess new risen up,/Is come with a great power to raise the siege" (1.6.79-81). Insinuating that "chaste" Joan is a whore, Talbot anglicizes her epithet, pronouncing pucelle, meaning "maid," as puzel, implying "whore": "Puzel or Pussel, Dolphin or Dog-fish," Talbot mocks his French enemies with chauvinistic insouciance before threatening, "Your hearts Il stampe out with my horse's heels/And make a quagmire with your mingled braines" (1.6.85-87). ${ }^{34}$ Talbot's bloody boast is made to rally his soldiers - and Elizabeth's beleaguered subjects - against their French Catholic enemies. 
However, with the arrival of Joan's troops, the English retreat in disarray: "Our English troops retire; I cannot stay them," Talbot remarks with disgust, "A woman clad in armour chaseth men." Then, he challenges Joan to fight while accusing her of witchcraft, "Devil or devil's dam, I'll conjure thee./ Blood will I draw on thee-thou art a witch - /And straightway give thy soul to him thou serv'st" (1.7.2-4 \& 5-8). Like the Dauphin, Talbot cannot defeat Joan; but unlike the Dauphin, Talbot prays, "Heavens, can you suffer hell so to prevail?" Then, he vows, "My breast I'll burst with straining of my courage/... But I will chastise this high-minded strumpet" (1.7.9-12). Joan withdraws from the duel to "victual Orleans" and taunts Talbot, "Go, go, cheer up thy hungry-starved men" $(1.7 .14,16)$.

In hand-to-hand combat, Joan fails to defeat Talbot; but in a duel, she has overcome the Dauphin with her sword. In a later scene, Shakespeare dramatizes a further contrast between the English hero and the French prince: whereas the Dauphin, a "fleshly man" burning with desire, is made Joan's "warlike mate," Talbot slips the snares of a French countess, a femme fatale who lures him into a trap. A messenger in the field tells Talbot that the "virtuous lady, Countess of Auvergne" invites him "to visit her poor castle where she lies" $(2.2 .38,41)$. Talbot agrees to visit, and the countess's "plot is laid" against him: she prepares to lock Talbot in her castle, suggesting that she means to have him killed there (2.3.4-10). On first seeing Talbot, "this dreadful knight" whose "glory fills the world with loud report" (2.3.7; 2.2.43), the countess expresses surprise and contempt for the English lord, great by reputation but small in body.

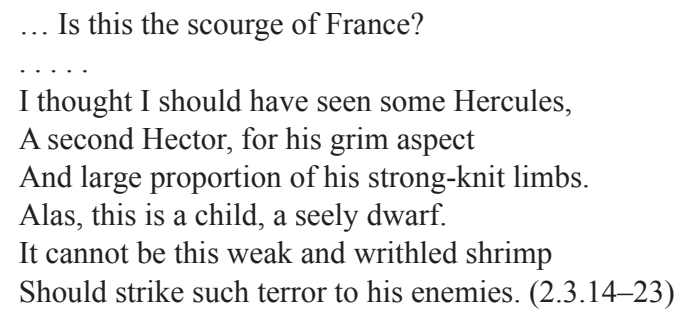

Here, the countess is misled by Talbot's appearance, calling him "a child," or a "dwarf," and, insinuating sexual inadequacy, a "weak and writhled shrimp." Soon after, with the castle doors locked, the countess tells Talbot that she has used image magic to draw him to her and make him her prisoner: "Long time thy shadow hath been thrall to me,/For in my gallery thy picture [image] hangs;/But now the substance shall endure the like," she warns, "And I will chain these legs and arms of thine" (2.3.35-38). ${ }^{35}$ In response, Talbot taunts the countess with a paradox, the confusion of substance with shadow. "I 
laugh to see your ladyship so fond/To think that you have aught but Talbot's shadow/Whereon to practice your severity" (2.3.44-46), he answers, placing little importance upon his body:

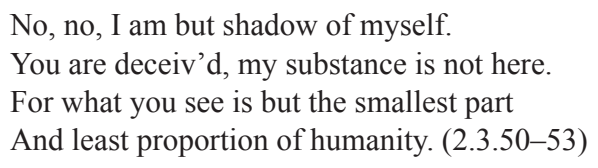

Then, Talbot blows a horn to summon his soldiers: "These are [my] substance, sinews, arms, and strength" (2.3.63). The countess is forced to admit that Talbot is "more than may be gathered by [his] shape" (2.3.69). Throughout 1 Henry 6, Shakespeare emphasizes Joan's corporeality and the Dauphin's carnal debility while suggesting that Talbot's strength derives from his lack of corporeality.

Misled by "the outward composition" of Talbot's "body" (2.3.75), the mere "shadow" of his being, Shakespeare's countess, deceived by appearance, displays a weakness attributed to Roman Catholics, a weakness that draws them to "false" religion, to "the church or chapel of the devil," according to Protestant apocalyptic ideology. ${ }^{36}$ Talbot, however, doubting the countess's expressed intentions, prepares himself against her deception. The contrast between Shakespeare's Talbot, with his strength against feminine wiles, and the Dauphin, in his submission to Joan, has thematic significance deriving in part from Tudor apocalypticism, with chastity a sign of election and with enthrallment under sexual desire a symptom of spiritual corruption. Immediately before introducing the Whore of Babylon in his Book of Revelation, St. John praises God's elect who stand with the Lamb on Mount Zion: "These are they, which are not defiled with women: for they are virgins ..." (Rev. 14.4). Thus, having extolled male virginity, St. John introduces his Whore with an admonition that women defile men. In Purity and Danger, a social anthropological study of pollution and taboo, Mary Douglas recalls that in many cultures contact with the opposite sex threatens defilement. She argues that "sexual dangers" are "better interpreted as symbols of the relation between parts of society" ordered in "a hierarchy" and that notions of "sex pollution" arise "from the desire to keep straight the internal lines of the social system." "Applying this general analysis of sexual pollution to gynophobia in 1 Henry 6, we see Joan's duel with the Dauphin and his ensuing sexual obsession as "defilements" of social order in contact between a low-born "manly" woman and her noble lord. Further, we may examine Talbot's escape from the countess's trap in light of the "Delilah complex" - according to Douglas, the fear that contact with a woman might rob a man of his powers. ${ }^{38}$ Evading 
the countess's trickery-her attempt to tie him in chains - "writhled" Talbot raises his stature as a Christian knight.

Such notions of purity and sexual pollution, implicit in St. John's Revelation, especially in his figure of the Great Whore, shape Shakespeare's characterization of Talbot's son John as a "virgin" warrior. With a small English force, Talbot lays siege to Bordeaux, where his young son arrives to fight in his first battle. The English have been surprised and encircled by a superior force. "Now thou art come unto a feast of death,/A terrible and unavoided danger," Talbot warns John before ordering him to flee (4.5.7-8); but John resolves to fight alongside his father, vowing, "For live I will not if my father die" (4.5.51). John is "hemmed about" by French soldiers. In the desperate battle, Joan "encounters" John and challenges him: "Thou maiden youth, be vanquished by a maid." John answers, "Young Talbot was not born/ To be the pillage of a giglot wench," before he "rush[es] in the bowels of the French" (4.7.38-42) where he "Did flesh his puny sword in Frenchmen's blood," as the Bastard of Orleans will recall with sexual innuendo (4.7.36). Similarly, Lord Talbot describes his son's first battle wound figuratively as loss of his maidenhead. Talbot comforts his son during a brief respite from combat:

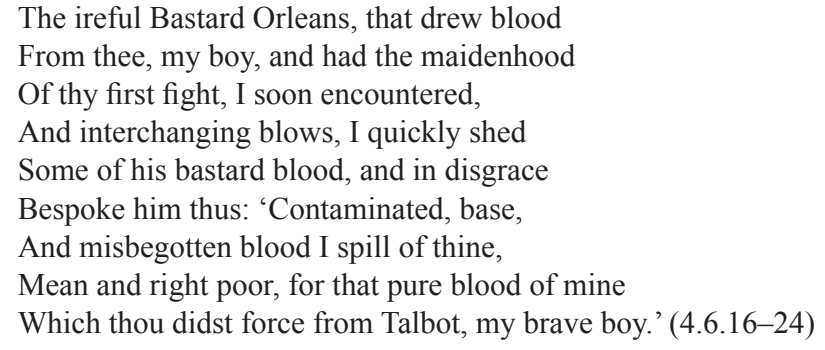

Young Talbot, the virgin knight, fights alongside his father for "God and St. George" while the Bastard of Orleans, paradoxically a noble of "contaminated, base and misbegotten blood," fights alongside the Dauphin and his "warlike mate," Joan la Pucelle, a whorish witch. In light of Tudor apocalyptic ideology, Shakespeare's juxtaposition of young Talbot against the Bastard of Orleans is emblematic of presumed ontological difference between Elizabeth's Protestant subjects and her French Catholic enemies. 
Among other cryptic prophecies in the Book of Revelation, the stripping of the Whore of Babylon received special attention among Elizabethan authors. St. John foresees that "they that shal hate the whore ... shal make her desolate and naked, \& shal eat her fleshe, \& burne her with fyre" (Rev. 17.16). In climactic verses of The Faerie Queene, Book One, Spenser, invoking the corporeal iconography of Protestant apocalyptic, describes the stripping of Duessa in starkly misogynistic detail. At the behest of Una, Arthur strips "that wicked woman," "that witch." "Ne spared they to strip her naked all" ( $F Q$ 1.8.46). With poetry crafted to elicit visceral response, Spenser devotes three stanzas to cataloguing the "misshaped parts" of the "loathly, wrinckled hag," her "secret filth" and "nether parts, the shame of all her kind." "Her dried dugs," the poet writes, "like bladders lacking wind,/Hong downe, and filthy matter from them weld" (FQ 1.8.46-48). ${ }^{39}$ Whereas Spenser, in his allegorical romance, pens a grotesquely literalistic elaboration of St. John's single verse, John Foxe and Thomas Dekker, in their allegorical dramas, represent the stripping of the whore as metaphor. Dekker's The Whore of Babylon, based in part upon The Faerie Queene, celebrates Elizabeth's ultimate victory over Spain and the Catholic League as the Faerie Queene's triumph over the Empress of Babylon, "under whom is figured Rome." In defeat, the Empress is "stripped" of her unholy powers. In Christus Triumphans, Foxe's allegorical "comedy," the stripping of the Whore, Pornapolis, is represented as the unmasking of papal superstition and the resultant Reformation in Europe, with Protestants "diligently reading scriptures - stonecutters, smiths, potters, everybody." 40 In 1 Henry 6, Joan, feigning Godliness and virginity, is exposed as a whorish witch. Thus, her stripping is figurative, but Shakespeare distorts and contradicts the historical record, inventing material to mark Joan's character with signal characteristics of St. John's Whore of Babylon.

Staging the reversal of Joan's military fortunes and her subsequent capture and trial by English knights, Shakespeare embellishes the conventional pattern of de casibus tragedy with non-historical incidents and symbolic acts recalling St. John's prophecies. Presumably aided by her familiar spirits, Joan leads the Dauphin's army to surprise English troops besieging Bordeaux. Lord Talbot suffers heroic death while embracing the lifeless body of his valiant son: "My spirit can no longer bear these harms," Talbot laments before dying, "Now my old arms are young John Talbot's grave" (4.7.30,32). After the battle, when an English knight enters searching for Talbot, Joan gloats, "Him that thou magnifi'st .../Stinking and flyblown lies here at our feet" 
(4.7.75-76) ${ }^{41}$ Soon after, Richard Duke of York, having joined the battle too late to rescue Talbot, routs the French.

To resolve any doubt whether Joan's supernatural powers are divine or demonic, Shakespeare, in a non-historical scene, reveals that Joan has relied upon sorcery routinely. Alone on the stage, with thunder sounding, Joan conjures:

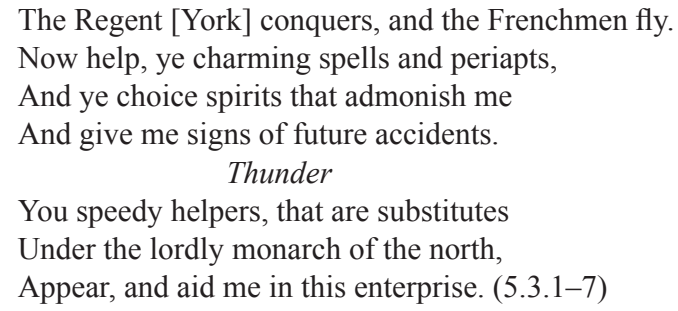

Her "familiar spirits," "culled" from "powerful regions under earth," make a "quick appearance" upon the stage, a sign of their "accustomed diligence;" but they do not speak, so Joan bargains with her devils: "Where I was wont to feed you with my blood,/I'll lop a member off and give it you .../So you do condescend to help me now" (5.3.9-17). The devils only "hang their heads," so Joan offers her body, then her soul before they leave the stage without responding. Joan admits that, without the help of her evil spirits to counter English valour, "France must vaile her lofty-plumed crest/And let her head fall into England's lap" (5.3.25-26). Abandoned by hell, Joan is soon captured.

In his interpretation of this scene, James J. Paxson focuses on "the feminine status of the demonic and the demonic status of the feminine" among Shakespeare's audience, with Joan "a kind of embodied demon or devil."42 I argue further that Shakespeare's characterization of the French saint exploits contemporary fear of a woman's body as the site of intercourse between humankind and Satan with his evil spirits, a gynophobia that motivated the North Berwick witch trials. From November 1590 until December 1591, the year before 1 Henry 6 premiered, Scottish authorities conducted witch hunts in North Berwick and other districts of East Lothian, where the Protestant Kirk "campaigned against both cunning folk and catholics, though the distinction was often unclear," according to recent analysis. Contrary to accepted practice, Scottish King James VI and his Privy Council in Edinburgh participated directly in these prosecutions by examining, trying, and sentencing accused witches. ${ }^{43}$ Among these, the "elder Witch," Agnis Sampson, charged with leading a demonic conspiracy against James, admitted only under prolonged torture that, at the behest of Satan, she had tried to harm James with black 
magic because the king was "the greatest enemy" that the devil had "in the worlde." "44 As in 1 Henry 6, the central conflict of the North Berwick trials is represented as an assault by Satan and his witch upon God's Protestants, whose righteousness is reconfirmed by such assault.

King James's witch trials gained notoriety from Edinburgh to London with a series of pamphlets that reported on events as they occurred. To give a "true" account of the proceedings, one of James's inquisitors, probably the Protestant minister James Carmichael, published Newes from Scotland in 1591, a brief "Historye" largely corroborated by recent investigation of court records. This pamphlet gives insight into the popular fears that Shakespeare most exploited in his Joan. Significantly, it recalls commonplace lore that witches have carnal relations with their devils when it reports that Agnis Sampson and others from North Berwick "confessed that when the Diuel did receive them for his servants ... he would Carnallye vse them ...."45 Similarly, in Shakespeare's non-historical scene, after Joan conjures her familiar spirits, she offers them her body to enlist their aid. Thus, Shakespeare plays upon his contemporaries' fears that women are prone to sexual infidelity and, thereby, subversion of a social order "ordained by God," fears given cosmic significance by contemporary religious ideology. In his Daemonologie, James reconfirms such longstanding fear of and loathing for women's presumed sensuality, their inclination to sin as daughters of Eve. "What can be the cause that there are twentie women given to that crafte [witchcraft], where there is one man?" asks Philomathes, an interlocutor in James's dialogue. "The reason is easie," answers Epistemon for the royal author, because that "sexe sensine" is "frailer than man" and "easier to be intrapped in these grosse snares of the Devill, as was well proved ... by the Serpents deceiving of Eve at the beginning ...."46

In 1 Henry 6, Talbot and York declare with certainty that Joan is a whore and a witch, charges that Joan denies, claiming to be a virgin "Chaste and immaculate in very thought" (5.6.51) soon after the audience has heard her offer her body to the evil spirits whom she has conjured. In Newes from Scotland, the accused witches also denied the charges made against them, even under torture, at least for a time. Agnis Sampson was examined before "sundry ... of the nobility of Scotland" and "the Kings Maiestie," who "tooke great delight to bee present at their examinations"; but Agnis "stood stiffely in the deniall of all that was laide to her charge." And so she was taken to prison, "there to receive such torture ... provided for witches in that countrey," but she still refused to confess. The prosecutors knew, however, that "the Devill dooth generallye marke" his witches "with a priuie marke" where he "doothe lick them with his tung in some priuy part of their bodie ...," so "by special 
commaundement this Agnis Sampson had all her haire shaven off, in each parte of her bodie, and her head thrawen with a rope ... being a paine most greevous, which she continued almost an hower, during which she would not confesse any thing vntil the Divels marke was found upon her priuities." 47 Naked before her inquisitors, stripped even of her body hair, the "Elder witch" Agnis confessed and was sentenced to death, her body burned after her death by strangulation on January 28,1591 . The following year, Shakespeare's 1 Henry 6 premiered on the London stage, an extraordinary theatrical success, taking £3 16s 8d for its first performance, "the highest" box-office "of the season." 48

The "witch" Agnis Sampson was stripped of her clothing, and her body was shaven; but according to John Bale's influential Tudor interpretation of Revelation, the stripping of the Whore occurs figuratively when faithful Christians strip "that Babylonish harlot Rome" of her "beauty." 49 When Shakespeare's Joan is captured, her stripping has already begun with her loss of beauty. "See how the ugly witch doth bend her brows," observes York (5.4.5): Joan has lost the attractions that, as she claimed, "God's mother" gave her during a heavenly apparition when Joan was transformed from a "black and swart" shepherdess into a seductive warrior. Whereas Hall writes that Joan had a "foul face" and Holinshed calls her "likesome" in appearance, none of Shakespeare's known sources claims that Joan was transformed from foul to fair or from fair to foul.

The Book of Revelation charges that the Great Whore has "committed fornication" with "Kings of the earth" (Rev. 17.2). Similarly, Shakespeare contradicts an important part of the historical record to suggest that, like St. John's Whore, Joan has "fornicated" with Catholic kings even as she claims to be a virgin. When York calls for "that sorceress condemned to burn" (5.6.1), Joan pleads to save herself from the flames, warning York that she "hath been/A virgin from her tender infancy,/Chaste and immaculate in very thought," and that if she is executed, her "maiden blood" will "cry for vengeance at the gates of heaven" (5.6.49-53). York dismisses Joan's claim to be a virgin. "Aye, Aye," he says, "Away with her to execution" (5.6.54). So Joan appeals to other legal grounds for commuting her sentence, that she is pregnant: "Then Joan, discover thine infirmity,/That warranteth by law to be thy privilege:/I am with child, ye bloody homicides./Murder not then the fruit within my womb" (5.6.60-63). York concludes that "She and the Dauphin have been ingling." Only after York insists on burning the Dauphin's unborn child together with Joan does she claim that her baby belongs to the French Duke of Alencon, and then to the King of Naples. York is adamant: "And yet, forsooth, she is a virgin pure!-/Strumpet, thy words condemn thy brat 
and thee" (5.6.65-84). Only Shakespeare's Joan admits to "fornicating" with kings.

In this scene, as Joan confesses to sexual transgressions, York and members of Shakespeare's audiences are invited to look at her body. According to Holinshed, English prosecutors "examined" Joan and found her a virgin; and so, she was sentenced to "perpetual prison" so long as she "cast off hir unnaturall wearing of mans habiliments" and "abjure[d] her pernicious practices of sorcerie and witcherie." Only after being accused of relapsing was Joan condemned to death; and only then, to save herself, did she claim to be pregnant. The English postponed Joan's execution for nine months and eight days to determine that she had lied about her condition. ${ }^{50}$ According to Holinshed, Joan was a virginal sorceress, but Shakespeare contradicts this fact of the historical record: his portrayal of Joan as a "strumpet" who feigns virginity is designed to evoke heightened theatrical effect among Elizabethan audiences by exploiting a specific theme of Protestant apocalyptic propaganda. St. John's Great Whore offers "a cup of golde in her hand, ful of abominations, and filthiness of her fornication" (Rev. 17.4). For Tudor controversialists, the cup represents the "execrable faith of that Romish religion," whose ministers claim "perpetual virginity" while practising "prodigious beastliness in lecherous living under colour of chastity." 51

Before claiming to be "with child," Shakespeare's Joan declares, "Joan, discover thine infirmity" (5.6.60). Whereas York has quickly rejected her claim to be a virgin innocent of sorcery, he readily admits that she is pregnant and sends her "brat" to die with her: "It dies and if it had a thousand lives" (5.6.75). The text of 1 Henry 6 lacks stage direction where Joan reveals her "infirmity," but York accepts Joan's word perhaps because she has opened her cloak to give York "ocular proof" of her condition. Such stage business would recall, as a symbolic act, the apocalyptic motif of the stripping of the whore; but whether or not Joan displays her body, we may assume that York looks at it, and draws the audience to do the same, before Joan is led away to be burnt. According to Nashe, members of Shakespeare's audiences wept when they saw Talbot, "in the Tragedian that represent[ed] his person," "fresh bleeding" on the stage. How did those audiences respond when Joan, apparently pregnant, was led to the flames? Capitalizing on tender response to Talbot's death, Shakespeare follows with Joan's execution, a second climax, to satisfy his audience's desire to witness revenge against the whorish Catholic witch who set the powers of hell against Godly Lord Talbot. More importantly, at a time when Elizabeth's troops are fighting for the Protestant cause in France, Shakespeare represents Joan as an avatar of the Great Whore 
to arouse a sense of national pride that valiant English knights have sacrificed themselves in battle against the ungodly forces of Catholic France.

Considering Shakespeare's imaginative embellishment of sources, including his scenes of sorcery and witchcraft, Geoffrey Bullough characterizes 1 Henry 6 as more "a fantasia on historical themes" than a chronicle play. ${ }^{52}$ Shakespeare does embellish and contradict the chroniclers' accounts; however, as feminist critics have demonstrated, the historicity of Shakespeare's Joan lies in his distortion of the historical record. In his "slanderous" portrayal of Joan, Shakespeare discloses elements of a misogyny current among his Elizabethan audiences. And so, to dismiss Shakespeare's characterization of Joan as fanciful theatrics is to discount his highly successful manipulation of a gynophobia inflamed by Protestant propaganda during Elizabeth's struggles against her enemies in the Catholic League. By representing Joan as a whorish witch like the Great Whore, Shakespeare alerts his audience to a presumably literal truth in St. John's prophecies, thus endorsing the Book of Revelation as a key to history. More importantly, Shakespeare's characterization of Joan exposes the lineaments of a misogyny propagated by early modern Christian apocalypticism. When, in metaphoric expression, the angel of Revelation warns about "great Babylon, the mother of whoredomes, and abominations of the earth," he describes spiritual corruptions as issuing from the body of a woman (Rev. 17.5). The angel then foretells that the Whore shall be stripped and burnt to purge the earth of her spiritual "fornications" (Rev. 17.16). He thus extends the allegorical personification to suggest that evil may be expelled with the destruction of a woman's body. Indeed, with the torture, stripping, strangulation, and burning of Agnis Sampson during the North Berwick witch trials, King James's prosecutors destroyed the woman's body that, as they had concluded, was a site of intercourse between Satan and James's enemies. Similarly, when Shakespeare's York sends Joan offstage to be burnt, he expels and destroys the body of the woman who, as a consort of evil spirits and Catholic kings, has threatened God's Englishmen.

\section{Texas A\&M University-Texarkana}

\section{Notes}

In writing this article, I owe a debt of gratitude to Prof. Huston Diehl for demonstrating that the Reformation enlivened Tudor drama with the tensions of rapid cultural change. I am also grateful to Ms. Darcie Ryan for her assistance and to librarians Melba Surman and Neisha 
Federick for their prompt efficiency in supplying materials that would have remained unavailable to me without their help.

1. Thomas Nashe, Pierce Penilesse, His Svpplication to the Divell (1592), ed. G. B. Harrison, Elizabethan \& Jacobean Quartos (New York: Barnes and Noble, 1966), p. 87; and regarding performances of "harey the vj" between March and June, 1592, see Phyllis Rackin, "Women's Roles in the Elizabethan History Play," The Cambridge Companion to Shakespeare's History Plays, ed. Michael Hattaway and Alfred Harbage (Cambridge and New York: Cambridge University Press, 2002), p. 76. Stanley Wells, Shakespeare: A Life in Drama (New York: Norton, 1997), emphasizes that the premier performance took $£ 316 \mathrm{~s} 8 \mathrm{~d}$, "the highest" box-office "of the season" (p. 88).

2. For example, in Historical Tales from Shakespeare (New York: Scribner, 1900), Arthur Quiller-Couch wishes that Shakespeare "had no hand in the slanderous portrait of Joan of Arc sent down to us under his name" (p. v). In his edition of The First Part of King Henry VI: The New Cambridge Edition (Cambridge: Cambridge University Press, 1952), J. Dover Wilson calls it "one of the worst plays in the canon" (p. ix). E. M. W. Tillyard, Shakespeare's History Plays (New York: Barnes and Noble, 1944), discounts misogyny in the play by treating Joan merely as an instrument of divine providence (p. 164). In Shakespeare's Early History Plays: From Chronicle to Stage (Oxford and New York: Oxford University Press, 2003), Dominique Goy-Blanquet recalls that 1 - 3 Henry 6 "fell back into their limbo" in the early 1960s after critics rejected Tillyard's overarching thesis that the first tetralogy forms part of Shakespeare's "grand epic of Tudor England" (Goy-Blanquet, p. 1).

3. The Tudor chronicler Edward Hall, The Union of the Two Noble and Illustre Famelies of Lancastre \& Yorke (1542; London: G. Woodfall, Paternoster Row, 1809), describes Joan as a "wytch or manly woman," a "supersticious sorceresse, and a diabolical blasphemeresse" who went "clothed in a mannes apparell, a thyng in the sight of God abominable" (pp. 157-58).

4. Feminist critics have revived interest in the first Henriad, especially in their analysis of Shakespeare's Joan. Leah S. Marcus suggests that Shakespeare's depiction of Joan evokes a predictable reaction against "female dominance." See Marcus's Puzzling Shakespeare: Local Reading and Its Discontents (Berkeley: University of California Press, 1988), p. 76. Similarly, in The End Crowns All: Closure and Contradiction in Shakespeare's History (Princeton, N.J.: Princeton University Press, 1991), Barbara Hodgdon describes Joan as a "subversive challenge" to patriarchal authority (p. 55); and in Women's Matters: Politics, Nation, and Gender in Shakespeare's Early History Plays (Newark: University of Delaware Press, 1998), Nina S. Levine examines Shakespeare's portrait of "an emasculating Joan" and reads her as a case study in the "unnatural female dominance" when Elizabeth ruled England (pp. 37, 27). With Engendering a Nation: A Feminist Account of Shakespeare's Histories (London and New York: Routledge, 1997), Jean E. Howard and Phyllis Rackin focus on Joan's theatricality, her "feminine theatrical subversion" of "patriarchal domination" (pp. 44-58). See also Rackin, "Foreign Country: The Place of Women and Sexuality in Shakespeare's Historical World," Enclosure Acts: Sexuality, Property, and Culture in Early Modern England, ed. Richard Burt and John Michael Archer (Ithaca: Cornell University Press, 1994), pp. 68-95, especially pp. 71-72; Rackin, Stages of History: Shakespeare's English Chronicles (Ithaca: Cornell University Press, 1990), pp. 146-58; Lisa Jardine, Still Harping on Daughters: Women and Drama 
in the Age of Shakespeare (Sussex: Harvester Press, 1983), pp. 105-06, and, on Joan's attire, pp. 156-59; and Catherine Belsey, The Subject of Tragedy: Identity and Difference in Renaissance Tragedy (London and New York: Methuen, 1985), pp. 183-85.

5. Geoffrey Bullough, Narrative and Dramatic Sources of Shakespeare, 8 vols. (London: Routledge and Paul, 1957-75), vol. 3, p. 24.

6. To examine political and religious elements in 1 Henry 6 , several critics rely on topical and ideological approaches. In "Topical Ideology: Witches, Amazons, and Shakespeare's Joan of Arc," English Literary Renaissance 18.1 (1988), pp. 40-65, Gabrielle Bernhard Jackson develops a broad interpretation of Joan as a strong woman, arguing that she performs "inconsistent ideological functions" in response to "types of the Amazon" and the "witch," "objects of fascination" for Shakespeare's audience (p. 44). (I argue that Shakespeare's use of religious ideology conflates the culturally charged figures of witch and woman-warrior in Joan.) With Puzzling Shakespeare, Marcus, stressing the importance of political conditions, recommends "localized" interpretation as part of "a major epistemological shift" to "less rigidly positivistic vantage points" (p. 50). Accordingly, she examines Shakespeare's Joan, "a woman who 'acts like a man', " as "a distorted image of Elizabeth" (pp. 52-53). In Tudor Drama and Politics: A Critical Approach to Topical Meaning (Cambridge: Harvard University Press, 1968), David Bevington recognizes a synergy between political and religious ideologies. Documenting the interplay between major historical events and theatre during the Tudor period, he emphasizes that use of art "as a weapon of propaganda was a commonplace in the sixteenth century" and that during the mid-century, "religious politics was virtually the whole substance of drama" (p. 3). More recently, in Staging Reform, Reforming the Stage: Protestantism and Popular Theater in Early Modern England (Ithaca and London: Cornell University Press, 1997), Huston Diehl argues that "Elizabethan and Jacobean drama is... a product of the Protestant Reformation" (p. 1); and in Shakespeare, Marlowe and the Politics of France (New York: Palgrave, 2002), Richard Hillman emphasizes that, in his portrait of Joan, Shakespeare interweaves contemporary Elizabethan anti-Catholic and anti-French propagandistic commonplaces (pp. 130-40).

7. John Foxe, Actes and Monuments of These Latter and Perillous Dayes, Touching Matters of the Church, ed. Stephen Reed Cattley, 8 vols. (1560; London: R. B. Seeley and W. Burnside, 1837), vol. 3, p. 580. It was after the failed Northern Rebellion of Roman Catholics that English bishops ordered Foxe's book to be furnished in cathedral churches and in the homes of ministers and church officials. Many parish churches provided copies as well. In John Foxe and His Book (London and New York: Society for the Promotion of Christian Knowledge, Octagon Books, 1940), J. F. Mozley traces the influence of Actes and Monuments in its four English editions before 1590 (pp. 137-51).

For examination of Tudor apocalyptic beliefs, see Richard Bauckham's Tudor Apocalypse: Sixteenth Century Apocalypticism, Millennarianism and the English Reformation, The Courtnay Library of Reformation Classics 8 (Sutton: Courtnay Press, 1978); Katherine R. Firth's The Apocalyptic Tradition in Reformation Britain 1530 - 1645 (Oxford and New York: Oxford University Press, 1979); Paul Christianson's Reformers and Babylon: English Apocalyptic Visions from the Reformation to the Eve of the Civil War (Toronto and Buffalo: University of Toronto Press, 1978); C. A. Patrides and Joseph Wittreich's The Apocalypse in English Renaissance Thought and Literature: Patterns, Antecendents, and Repercussions (Manchester [Eng.] and Dover, New Hampshire: Manchester Uni- 
78/ Renaissance and Reformation / Renaissance et Réforme

versity Press, 1984); and Frank R. Ardolino's Apocalypse \& Armada in Kyd's Spanish Tragedy, Sixteenth Century Essays \& Studies 29 (Kirksville, MO: Sixteenth Century Journal Publishers, 1995).

8. Except where stated otherwise, references to Shakespeare's 1 Henry 6 are cited in the text by act, scene, and line numbers from William Shakespeare: The Complete Works, gen. ed. Stanley Wells and Gary Taylor (Oxford: Clarendon Press, 1986).

9. References to the Bible are cited in the text by book, chapter, and verse from The Geneva Bible: A Facsimile of the 1560 Edition (Madison: University of Wisconsin Press, 1969).

10. With his woodcut illustrations of the Book of Revelation in Martin Luther's Das Newe Testament Deutzsch (Vuittemberg, September 1522), also known as the "September Bible," Lucas Cranach develops a nascent early modern tradition of apocalyptic iconography. The artist of the Cologne Bible and Albrecht Durer were his most notable predecessors. See Willi Kurth, ed., The Complete Woodcuts of Albrecht Durer (1927; New York: Dover Publications, 1963), p. 20.

11. Jan van der Noot, A Theatre for Voluptuous Worldlings (London, 1569; New York: Scholars' Facsimile and Reprints, 1936), woodcut D.v., "The faithfull man with flaming countenaunce," opposite the apocalyptic sonnet, "Then might I see upon a white horse."

12. Edmund Spenser, The Faerie Queene, ed. A. C. Hamilton (London: Longman, 1977), Book 1, Canto 11. References to Spenser's Faerie Queene are cited in the text by book, canto, and stanza numbers.

13. John Bale, The Image of Bothe Churches after the Moste Wonderfull and Heavenly Revelation of St. John, in Select Works of John Bale, Pt. 2, vol. 1, ed. Rev. Henry Christmas, Parker Society Publications (Cambridge: Cambridge University Press, 1849), pp. 49394. Bale follows Martin Luther. With his Protestant manifesto The Babylonian Captivity of the Church (1520), trans. Charles Michael Jacobs, Three Treatises: Martin Luther (Philadelphia: Fortress Press, 1960), Luther identifies the "tyranny of Rome" and the papacy with Babylon (pp. 123-24), a commonplace of subsequent Protestant apocalyptic eschatology and rhetoric. After the death of King Henry VIII in 1547, Bale returned to England from exile in Germany and, under the aegis of Protestant Edward VI, continued his long career as a Reformation propagandist with Image of Bothe Churches, a commentary on St. John's Book of Revelation and a comprehensive synthesis of Protestant apocalyptic. Having lived as Bale's roommate in exile, John Foxe incorporated many similar apocalyptic beliefs into his Actes and Monuments.

14. See as representative works Heinrich Bullinger's $O f$ the end of the world and iudgement of our Lord Jesus Christe to come, and of the moste perillous dangers of this our moste corrupt age... now lately englished by Thomas Potter (London: [John Allde, 1580?]); Stephen Batman's The Doome warning all men to Iudgemente: Wherein are contayned for the most parte all the straunge Prodigies hapned in the Worlde with diuers cecrete figures of Revelation (London: Ralph Nubery, 1581; facsimile rpt., introduction by John McNair, "Scholars' Facsimiles and Reprints" 394, Delmar; New York, 1984); William Fulke's De successione ecclesiastica et latente ab antichristi tyrannide ecclesia (London: Henry Middleton, 1584); and Abraham Fleming's A bright Burning Beacon... A discourse of the end of this world (London: Henry Denham, 1580). For a fuller list of such publications, see the bibliography in Patrides and Wittreich's The Apocalypse in English Renaissance Thought and Literature. 
In The History of the Most Renowned and Victorious Princess Elizabeth, Late Queen of England, 4th ed. (London: M. Flesher, 1688; facsimile rpt. New York: AMS, 1970), William Camden records in extraordinary detail "the fanatical Madness, or rather blasphemous Impiety," of William Hacket, a Presbyterian "of the vulgar sort" who, in 1591, enjoyed brief notoriety as an apocalyptic prophet. Claiming that he was "that very Angel to come before the Last day... to separate the Goats from the Sheep; and that he should tread down Satan under his feet, and totally subvert the Kingdom of Antichrist," Hacket threatened "to stir up the Multitude to Rebellion," and so was executed (pp. 451-52).

15. See Foxe, Actes and Monuments, vol. 1, p. xxiv. Andrew Penny (with "John Foxe, Actes and Monuments and the Development of Prophetic Interpretation," John Foxe and the English Reformation, ed. David Loades, St. Andrewes Studies in Reformation History [Hants, England: Scholar Press, 1997] pp. 252-77) examines Foxe's participation in the crudest form of apocalyptic rhetoric identifying the papacy as Antichrist, and the Roman church as the Whore of Babylon (p. 255). Thomas Betteridge, "From Prophetic to Apocalyptic: John Foxe and the Writing of History," in the same collection (pp. 210-23), traces, through successive editions of Actes and Monuments, Foxe's deepening pessimism amid rising apocalyptic expectations.

16. As noted by Bauckham in his Tudor Apocalypse, many Elizabethans attributed this prophecy to fifteenth-century mathematician and astrologer Regiomontanus:

When after Christs birthe there be expired of hundreds, fifteene yeers, eithtie eight

Then comes the time of dangers to befeared, And all mankind with dolors it shall fright:

For if the world in that yeere do not fall, If Sea and Land then perish ne dedaie:

Yet empires all and kindomes alter shall, And man to ease himself shall have no way. (quoted in Bauckham, p. 168)

England's defeat of the Armada, resulting as much from Spanish incompetence and bad weather as from English seamanship, seemed to fulfill the prophecy that "empires and kingdoms" should "alter" in 1588, Queen Elizabeth's annus mirabilis. See Bauckham, "The Wonderful Year," in his Tudor Apocalypse (pp. 162-84); Ardolino, "The "Annus Mirabilis' of 1588: Apocalypse and Armada," in his Apocalypse \& Armada (pp. 121-41); and Christianson's Reformers and Babylon (especially pp. 89-106).

17. Anne Somerset, Elizabeth I (London: Weidenfield and Nicolson, 1991), pp. 480-86. Camden, in his History of Elizabeth, emphasizes the role of religion in Protestant England's struggle with Spain and the Catholic League (p. 433).

18. For an examination of Duessa in Spenser's historical allegory, see Josephine Waters Bennet, The Evolution of the 'Faerie Queene' (Chicago: University of Chicago Press, 1942); Frank Kermode, "The Faerie Queene I \& IV," Essential Articles: Edmund Spenser, ed. A. C. Hamilton (Hamden Connecticut: Archon Books, 1972), pp. 267-88; and Elizabeth Heale, The Faerie Queene: A Reader's Guide (Cambridge and New York: Cambridge University Press, 1989). For an examination of misogyny and Spenser's Duessa, see Claire McEachern, The Poetics of English Nationhood, 1590-1612 (Cambridge and New York: Cambridge University Press, 1996), especially pp. 44-45; Harry Berger, Jr., "Displacing Autophobia in Faerie Queene I: Ethics, Gender and Oppositional Reading in 
the Spenserian Text," English Literary Renaissance 28 (1998), pp. 163-82; and Berger's "Sexual and Religious Politics in Book I of Spenser's Faerie Queene," English Literary Renaissance 34.2 (Spring 2004), pp. 201-43.

19. See Hall, p. 148. In "Overreachers, the 'circle in the water' and Force in 1 Henry 6," English Literary Renaissance 33.3 (October 2003), pp. 309-327, Michael Harrawood sees Joan as an "overreacher" and examines the irony in her describing an undular pattern in history.

20. In his translation of Fronton Du Duc's The Tragic History of La Pucelle of Domremy, Otherwise Known as The Maid of Orleans, Carleton Renaissance Plays in Translation 39 (Ottawa: Dovehouse Editions, 2005), Richard Hillman expresses "surprise" that Shakespeare allows the question "to remain so long in suspension" when in Du Duc's play Archangel Michael resolves the question very early (p. 173, n. 68). In most respects of characterization, Du Duc's drama stands a complementary opposite to Shakespeare's 1 Henry 6. Hillman examines strong circumstantial evidence that Du Duc's work may have influenced Shakespeare.

21. James VI of Scotland, Daemonologie (Edinburgh: Robert Waldegrave, 1597; facsimile rpt., Amsterdam: Theatrum Orbis Terrarum, 1969), p 21. Reginald Scot, in his Discoverie of Witchcraft, ed. Rev. Montague Summers (1584; New York: Dover Publications Inc., 1972), condemns the credulity of his fellow Elizabethans who believe in witches' "omnipotencie" (p. 4). Commenting on this incident, Hall charges that Joan, "a monster" in "mans apparell," was sent by Satan to delude the Dauphin (p. 157-58).

22. Lisa Jardine demonstrates that Joan's cross-dressing and wearing of a sword were likely to arouse strong reactions among Elizabethans, who used sumptuary laws to regulate men's and women's apparel (pp. 156-59).

23. Bullough, vol. 3 , pp. $56 \& 75$.

24. Geneva Bible, p. 280, n. i; and Foxe, Actes and Monuments, vol. 1, p. xix.

25. Bale, p. 259.

26. Claire McEachern, "Sects and the Single Woman: Spenser's National Romance," in her Poetics of English Nationhood, 1590-1612 (Cambridge and New York: Cambridge University Press, 1996), pp. 39-58. In her provocative reading, McEachern examines the source of a central psychological tension in Spenser's apocalyptic poem, the indeterminacy of woman - that is, the male believer's inadequacy to discern the faithful woman from the unfaithful, and by implication, the true from the false church, the chaste spouse of the Lamb from the Whore of Babylon. When Queen Elizabeth puts on her royal robes, has she bedizened herself in the regalia of John Knoxe's "monstrous regiment"? Does Elizabeth imitate the Whore of Babylon? McEachern asks (p. 58).

27. In King James's dialogue on Daemonologie, an interlocutor asserts that witcheraft is "rife" because Satan has realized that "his kingdome" is about to end (p. 81). Such apocalyptic anxieties contributed to an increase in prosecutions for witchcraft in Britain. See Alan MacFarlane's Witchcraft in Tudor and Stuart England (New York: Harper, 1970) for evidence that in early modern Essex accusations of witchcraft and sorcery peaked between 1580 and 1592 (p. 72). See also George Lyman Kittredge's Witchcraft in Old and New England (New York: Russell and Russell, 1929) regarding the "great Scottish prosecution" of witches between 1590 and 1597 (pp. 278-80).

28. James VI, Preface, p. 5 (unnumbered). 
29. Bale, p. 259. In his edition of 1 Henry 6 (Cambridge and New York: Cambridge University Press, 1990), Michael Hattaway discusses Shakespeare's allusion to Rhodope.

30. See, for example, Philipp Nicolai, De duobus Antichristi: Mahumete et Pontifice Romano (n. p., 1590).

31. Bale, pp. 261-63 \& 570-71.

32. John Aylmer, An Harborowe for Faithfull and Trewe Subjects, agaynst the late blown Blaste, concerning the Government of Wemen, The English Experience 423 (Strasforowe, 1559; Amsterdam: Da Capo Press Inc., 1972), Epistle to the Reader, p. v.

33. Christopher Marlowe's Tamburlaine, Part One and Part Two: Text and Major Criticism, ed. Irving Ribner (Indianapolis; Odyssey Press, 1974). For a description of Marlowe's Muslim hero as an instrument of divine providence, see Roy W. Battenhouse's "Tamburlaine, the 'Scourge of God'," Publications of the Modern Language Association of America 56.2 (June 1941), pp. 337-48; and for a comparison of Shakespeare's Joan to Marlowe's Tamburlaine, see Michael Harrawood, pp. 310-11.

34. I quote this line from The First Folio of Shakespeare (1623; Norton facsimile, New York: W. W. Norton, 1968), the earliest extant copy of 1 Henry 6. For meanings of puzel and pucelle in sixteenth-century English, see the Oxford English Dictionary under pucelle. As an anglicized pronunciation of the French pucelle, puzel more readily suggests whore.

35. For discussion of image-magic as a practice imputed to English witches in Shakespeare's time, see Keith Thomas's Religion and the Decline of Magic (New York: Charles Scribner's Sons, 1971), pp. 437-38 \& 513-14. See also King James's assertion that the devil "teacheth, how to make Pictures of waxe or clay ... That the persones that they beare the name of, may be ... dryed away with continuall sicknesse" (p. 44).

36. As noted above (p. 61), Foxe warns against the "church or chapel of the devil," that is, the "church of Rome to be so visible and glorious in the eyes of all the world, so shining in outward beauty, to bear such a port, to carry such a train and multitude, and to stand in such high authority" that it is "supposed... to be the only right catholic mother" (Actes and Monuments, vol. 1, p. xix).

37. See Mary Douglas's Purity and Danger: An Analysis of the Concepts of Pollution and Taboo (1966; rpt. New York and London: Routledge, 1991), pp. 3-4, and her chapter "The System at War with Itself," pp. 141-59.

38. For her examination of the Delilah complex, see Douglas, pp. 147-53.

39. McEachern considers psychological implications of the stripping of Duessa. Their exposing and examining "the animal nature"of Duessa's "genital half" will not assure the fairy knights that Una is true. If Una's robes were removed, the two different women "might become the same woman," hence, the threat that haunts Spenser's poem, set as it is in Fairy Land, a woman's realm (pp. 44-50).

40. Thomas Dekker, The Whore of Babylon by Thomas Dekker: A Critical Edition, ed. Marianne Gateson Riely (New York \& London: Garland, 1980), p. 93. John Foxe, Christus Triumphans, Comoedia Apocalyptica, in Two Latin Comedies by John Foxe the Martyrologist, ed. \& trans. John Hazel Smith (Ithaca \& London: Cornell University Press, 1973), pp. 347-49. 
41. Lord Talbot actually died more than twenty years after the execution of Joan of Arc. Goy-Blanquet provides thorough examination of Shakespeare's rather free adaptation of source materials for 1 Henry 6 (pp. 19-56).

42. "Shakespeare's Medieval Devils and Joan la Pucelle in 1 Henry VI: Semiotics, Iconography, and Feminist Criticism," Henry VI: Critical Essays, ed. Thomas A. Pendleton (Routledge: New York, 2001), pp. 127-156, especially p. 148.

43. Lawrence Normand and Gareth Roberts, ed., Witchcraft in Early Modern Scotland: James VI's Daemonology and the North Berwick Witch Trials (Exeter: University of Exeter, 2002), pp. 1-2, and 57-58 (quotation, p. 58). Normand and Roberts compile and edit extant legal documents from the North Berwick witch trials.

44. Newes from Scotland, in King James the First Daemonologie (1597) [and] Newes from Scotland declaring the Damnable Life and death of Doctor Fian, a notable Sorcerer who was burned at Edenbrough in Ianuary last (1591), ed. G. B. Harrison, The Bodley Head Quartos (London and New York: John Lane and E. P. Dutton, 1924), p. 15.

45. Newes from Scotland, p. 18; regarding the role of James Carmichael, Normand and Roberts, p. 4.

46. James VI, pp. 43-44.

47. Newes from Scotland, p. 13.

48. Regarding the execution of Agnis Sampson, see Normand and Roberts, p. 103; and regarding the premiere of 1 Henry 6, Welles, p. 88.

49. Bale, p. 509.

50. Bullough, vol. 3, pp. 76-77.

51. Bale, p. 497.

52. Bullough, vol. 3, p. 25 . 